\title{
Quality assessment of tiger nut milk fortified with Moringa oleifera seed powder
}

\author{
Aanuoluwa R. OSALONI*, Charles O. ARIJENIWA, Sunday O. BADA, \\ and Elliot O. SEYIFUNMI
}

\author{
Department of Science Laboratory Technology, Faculty of Applied Sciences, Rufus Giwa Polytechnic, P.M.B. 1019, \\ Owo, Nigeria
}

\begin{abstract}
In this study, the effect of fortification of tiger nut milk with moringa seed on the microbial, nutritional and sensory quality of the local beverage was investigated. Fortification of tiger nut milk significantly $(p \leq 0.05)$ reduced the fungal load of the drink with 8.00 as against 17.00 in the control sample. The organisms isolated from the freshly prepared tiger nut milk blends were Bacillus subtilis, Micrococcus luteus, Saccharomyces cerevisiae, Aspergillus niger, Rhizopus stolonifer and Penicillum species. Further, fortified milk had higher moisture (78.51\%), protein (2.97\%) and lipid (2.01\%) contents compared with the unfortified milk which had $76.83 \%, 2.11 \%$ and $1.45 \%$ respectively. Also, the ash, fiber and carbohydrate contents of the unfortified tiger nut milk were higher than that of the fortified tiger nut milk. Similarly, the fortified milk had higher level of all the minerals assessed than unfortified milk. In the sensory evaluation, tiger nut milk fortified with moringa seed had comparable rating to the unfortified milk in appearance, color, consistency and acceptability, but had a lower rating for taste and higher rating for aroma. These results suggest that moringa seed powder may be added to tiger nut milk to improve its nutritional quality.
\end{abstract}

Keywords: tiger nut milk, moringa, fortification, proximate, microbial, sensory.

\section{Introduction}

Tiger nut (Cyperus esculentum) is a perennial grass-like plant with spheroid tubers, pale yellow cream kernel surrounded by a fibrous sheath [1]. Tiger nut is found wild and cultivated in Africa, South America, Europe and Asia. Tiger nuts grow in the wild, along rivers and are cultivated on a small scale by rural farmers mostly in the northern states of Nigeria. Tiger nuts are edible, sweet, nutty, flavored tubers which contain protein, carbohydrate, sugars, and lots of oil and fiber [2].

Tiger nut is a tuber that grow freely and is consumed widely in Nigeria, other parts of West Africa, East Africa, parts of Europe, particularly Spain, as well as in the Arabian Peninsula [3]. The tiger nut milk was classified as medicinal drink due to it is highly energetic and diuretic, rich in mineral, predominantly phosphorus and potassium, and also in vitamins $\mathrm{C}$ and $\mathrm{E}$ [4].

Grossman and Thomas [5] showed that tiger nuts have been cultivated for food and drink for human consumption, and planted for hogs for many years in Spain, and that the lovely milky elixir is served as a refreshing beverage (competing successfully with other soft drinks). Unfortunately, despite these potentials in tiger nuts it has been a neglected crop in Nigeria.

Tiger nut could provide a basis for rural industries in Africa. It is an important food crop for certain tribes in Africa, often collected and eaten raw, baked as a vegetable, roasted or dried and ground to flour. The ground flour is mixed with sorghum to make porridge, ice-cream, sherbet or milky drink. It is mostly consumed raw as snack without knowledge of the food and nutritional quality. It has also been found to possess good therapeutic quality [6 - 8]. Moore [9] stated that "the expansion of tiger nut milky drinks will significantly help the research linking tiger nut milk to healthier cholesterol levels and other non-dairy manufacturers. This could also gain a boost from an increased consumer interest in health foods".

Moringa ( $M$. oleifera) is a member of Moringaceae family and it has been reported to be an effective remedy for malnutrition especially in sub-Saharan Africa. All the aerial parts of the plant including the leaf, flour, pods and seeds are reported to be of high nutritive value. Moringa is called a "wonder tree" in Africa where it is claimed that moringa contains "more vitamin $\mathrm{C}$ than oranges, more vitamin A than carrots, more calcium than milk, more protein than yoghurt, more potassium than bananas and more iron than spinach" [10]. Moringa is rich in phytosterols like stigmasterol, sitosterol and kampesterol which are precursors for hormones [10, 11].

Allen et al. [11] reported that countries like Senegal and Benin use moringa to treat malnutrition in children younger than 3 years. Also, the leaf powder can meet a woman's daily iron and calcium requirements during pregnancy. Incorporation of moringa seed into food materials can be significant to tackle nutrient deficiencies and malnutrition in Africa. Several studies have tried fortifying various foods with different parts of moringa, cookies made from a mixture of maize flour and moringa seed flour was evaluated by Allen et al. [11]. The blend made from $92.5 \%$ maize and $7.5 \%$ moringa seed flour combination had the best acceptance which may be due to its crispness, aroma, taste and

\footnotetext{
* Corresponding author. E-mail address: michaelococcus@gmail.com (Aanuoluwa R. Osaloni)
} 
color. Cereal gruels have also been fortified by moringa seed in order to improve the protein content and energy. The cereal gruel with $65 \%$ popcorn and $35 \%$ moringa seed was blanched and fermented. The fermented ones showed higher protein content and energy while the blanched cereal had higher mineral content [11].

Therefore, the specific objective of this research is to produce a moringa seed fortified tiger nut milk and assess its microbiological, nutritional and sensory qualities.

\section{Experimental}

\subsection{Materials}

The high purity reagents were obtained from Pascal Scientific Nig Ltd., being used as received without further purification.

\subsection{Collection and preparation of plant samples}

The tiger nut seeds and moringa seeds were sourced from Shasha market, Akure, Ondo state, Nigeria. The seeds were sorted and washed, then kept in sterile containers till further use.

\subsection{Sterilization procedure}

The glass wares were sterilized in hot air oven for 30 min at holding temperature of $180{ }^{\circ} \mathrm{C}$. Inoculating wire loop used were sterilized by flaming with a spirit lamp until red hot and then allowed to cool before using. The surfaces of the workbench were sterilized by wiping with cotton wool soaked in $75 \%$ alcohol before and after each working period.

\subsection{Production of unfortified and fortified tiger nut milk}

Fresh tiger nuts $(500 \mathrm{~g})$ were soaked in two changes of clean water for 12 hours. The soaked tiger nuts were washed in two changes of water, drained, blended into paste in electric blender (50 $\mathrm{g}$ of moringa seed was added at this point) and slurried. $2500 \mathrm{ml}$ of distilled water was used all together during the blending and slurring process. The slurry was filtered with the aid of a clean damp muslin cloth and the filtrate obtained was transferred into sterilized plastic bottles, corked and stored in the refrigerator prior to analysis.

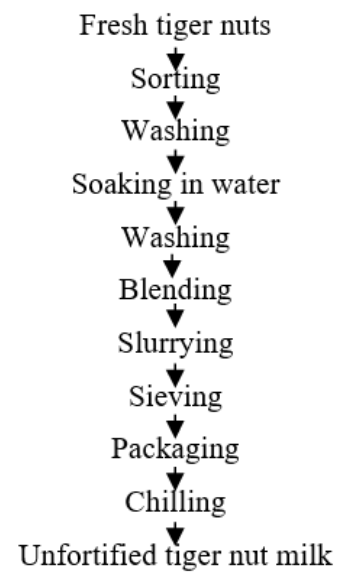

Figure 1. Flowchart for the production of tiger nut milk.

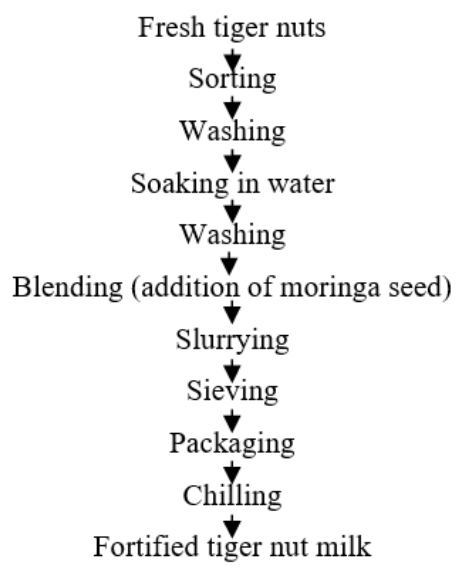

Figure 2. Flowchart for the production of fortified tiger nut milk.

\subsection{Media preparation}

The media used for this work include Nutrient Agar for isolation of total bacteria, Eosin Methylene Blue agar for isolation of coliforms, MacConkey agar for isolation of the enteric bacteria, and Potato dextrose agar for isolation of fungi. They were prepared strictly according to the manufacturer's specifications and then autoclaved at $121{ }^{\circ} \mathrm{C}$ for $15 \mathrm{~min}$.

\subsection{Microbiological analyses}

$9 \mathrm{ml}$ of distilled water were pipette into 5 clean test tubes each, they were covered with cotton wool and aluminum foil, and then they were autoclaved at $121{ }^{\circ} \mathrm{C}$ for $20 \mathrm{~min}$. The sample was macerated in a beaker, $1 \mathrm{~g}$ of the macerated sample was weighed into a sterile test tube containing $9 \mathrm{ml}$ of distilled water to make 1:9 of sample water ratio, i.e. $10^{-1}$. The mixture was shaken well to suspend the propagules then a sterile pipette was used to measure $1 \mathrm{ml}$ from the supernatant into another test tube containing $9 \mathrm{ml}$ sterile distilled water. The mixture was shaken to homogenize, the dilution factor was now $10^{-2}$. This procedure continued in sequential order until the last test tube which had dilution factor of $10^{-5}$ [12].

2.6.1.Isolation of microorganism. The pour plate method was adopted for the culturing of the organisms. $1 \mathrm{ml}$ of the aliquot of test tube containing dilution factor of $10^{-3}$ were dropped in pre-labeled separate sterile Petri dishes in duplicates, $20 \mathrm{ml}$ of molten agar at $45^{\circ} \mathrm{C}$ was poured on it and the Petri dishes were swirled to homogenize. The plates were allowed to solidify and then they were incubated inverted in incubator at $35^{\circ} \mathrm{C}$ for 18 to $24 \mathrm{~h}$ for nutrient agar, EMB and MacConkey agar plates, while MRSA plates were incubated anaerobically for $48 \mathrm{~h}$. Fungal plates were incubated at room temperature for 3 to 7 days. The colonies were counted after incubation and discrete colonies were subcultured on nutrient agar slant for further analysis.

2.6.2. Cultural and morphological characteristics of the colonies. The cultural and morphological characteristics of the colonies were observed based on the criteria of "Berger's Manual of Determinative Bacteriology" [12]. These include the following: shape of the colonies, the elevation, the edge, optical characteristics and pigmentation. 
2.6.3. Biochemical characterization. Biochemical characterization of the isolates was done including Gram staining reaction, sugar fermentation, oxidase, indole, Voges-Proskaeur, citrate, catalase, and coagulase tests.

2.6.4. Identification of fungi. Pure cultures of fungi isolates were characterized and identified based on the morphological characteristics of the organisms and confirmed by comparing them with the characteristics given in fungi data base. The morphological characteristic of the moulds were based on the size, color and aerial mycelia growth.

\subsection{Proximate analysis}

These were done following the standard methods of AOAC [13].

2.7.1. Moisture content determination. The moisture content was determined by using oven-drying method [13].

2.7.2. Ash content determination. $1 \mathrm{~g}$ of the sample was transformed in ash by burning of organic matter [13].

2.7.3. Fat content determination. The content of fat was determined using Soxhlet extraction, as in the method proposed by AOAC [13].

2.7.4. Protein content determination. Kjeldahl nitrogen method was employed for the determination of protein content of the sample [13], using a Kjeldahl apparatus from Accumax (India).

2.7.5. Fiber content determination. Fiber content was determined by the method of AOAC [13].

2.7.6. Carbohydrate content determination. Carbohydrate content was calculated by subtracting from 100 the sum of the percentage moisture, ash, protein, fat and fiber [13]. The remainder value gives the carbohydrate content of the sample.

2.7.7. Mineral content determination. The minerals calcium, potassium, sodium, magnesium and phosphorus present in the samples were assayed using the Atomic Absorbance Spectrophotometer (PEC Medical model 721, USA) as described by Johoun [14].

\subsection{Sensory evaluation}

This was done by 10 trained panelists selected randomly from Department of Science Laboratory Technology, Rufus Giwa Polytechnic, Owo, Ondo state. The nine point hedonic scale was used (score " 9 " having excellent attribute and score " 1 " indicating dislike extremely). Samples were coded with random alphabets. The properties evaluated were appearance, taste, aroma and overall acceptability [4].

\subsection{Statistical analysis}

All data were analyzed by using SPSS version 15. Data were analyzed using one-way analysis of variance (ANOVA), the Duncan's New Multiple Range Test was used to compare means at $95 \%$ confidence interval.

\section{Results and discussion}

\subsection{Results}

The microbial count on the freshly prepared moringa fortified tiger nut milk is shown in Table 1. The table revealed that lactic acid bacteria, coliforms and enteric bacteria were not found in the both samples. However, the highest total heterophilic bacterial count $\left(22 \times 10^{2}\right.$ $\mathrm{cfu} / \mathrm{ml}$ ) were found in the unfortified sample while the fortified sample had a count of $15 \times 10^{2} \mathrm{cfu} / \mathrm{ml}$ total bacteria. Further, the highest fungal count was found in unfortified sample $\left(17 \times 10^{2} \mathrm{cfu} / \mathrm{ml}\right)$ while the least count were observed on fortified sample $\left(8 \times 10^{2} \mathrm{cfu} / \mathrm{ml}\right)$.

Table 1. Microbial count on the tiger nut milk fortified with moringa seed powder (sample 2) in comparison with unfortified milk (sample 1) (x $10^{2} \mathrm{cfu} / \mathrm{ml}$ ).

\begin{tabular}{cccccc}
\hline Sample & $\begin{array}{c}\text { Total } \\
\text { bacterial } \\
\text { count }\end{array}$ & $\begin{array}{c}\text { Lactic } \\
\text { acid } \\
\text { bacteria }\end{array}$ & $\begin{array}{c}\text { Total } \\
\text { coliform } \\
\text { count }\end{array}$ & $\begin{array}{c}\text { Total } \\
\text { entero- } \\
\text { bacteriaceae } \\
\text { count }\end{array}$ & $\begin{array}{c}\text { Total } \\
\text { fungal } \\
\text { count }\end{array}$ \\
\hline $\mathbf{1}$ & $22.00 \pm$ & - & - & - & $17.00 \pm$ \\
& $0.01^{\mathrm{a}}$ & - & - & & $0.01^{\mathrm{b}}$ \\
$\mathbf{2}$ & $15.00 \pm$ & - & - & - & $8.00 \pm$ \\
\hline
\end{tabular}

*Values are mean $\pm \mathrm{SEM}$; values with different alphabet along the column are significantly different at $p \leq 0.05$.

A total of six organisms including two bacteria and four fungi species were isolated from the freshly prepared tiger nut milk blends, they were Bacillus subtilis, Micrococcus luteus, Saccharomyces cerevisiae, Aspergillus niger, Rhizopus stolonifer and Penicillium species (Table 2).

Table 2. Microbial quality of freshly produced kunu-zaki tiger nut milk blends

\begin{tabular}{lcc}
\hline \multicolumn{1}{c}{ Organism } & $\begin{array}{c}\text { Unfortified } \\
\text { sample }\end{array}$ & $\begin{array}{c}\text { Fortified } \\
\text { sample }\end{array}$ \\
\hline Bacillus subtilis & + & + \\
Micrococcus luteus & + & - \\
Saccharomyces cerevisiae & + & - \\
Aspergillus niger & + & + \\
Rhizopus stolonifer & + & + \\
Penicillum species & + & + \\
\hline
\end{tabular}

The result of the mineral composition of the tiger nut milk fortified with moringa seed is presented in Table 3. The table shows that the fortified milk had higher level of all the minerals than unfortified milk.

Table 3. Mineral composition of tiger nut milk fortified with moringa seed $(\mathrm{mg} / 100 \mathrm{~g})$.

\begin{tabular}{lcc}
\hline \multicolumn{1}{c}{ Mineral } & $\begin{array}{c}\text { Fortified tiger } \\
\text { nut milk }\end{array}$ & $\begin{array}{c}\text { Unfortified tiger } \\
\text { nut milk }\end{array}$ \\
\hline Calcium & $3.82 \pm 0.00^{\mathrm{a}}$ & $3.61 \pm 0.01^{\mathrm{a}}$ \\
Potassium & $43.81 \pm 0.01^{\mathrm{a}}$ & $37.09 \pm 0.01^{\mathrm{a}}$ \\
Sodium & $49.02 \pm 0.00^{\mathrm{b}}$ & $32.10 \pm 0.01^{\mathrm{a}}$ \\
Magnesium $_{\text {Phosphorus }}$ & $28.05 \pm 0.01^{\mathrm{a}}$ & $25.11 \pm 0.01^{\mathrm{a}}$ \\
\hline
\end{tabular}

In the sensory evaluation, tiger nut milk fortified with moringa seed had comparable rating to the unfortified milk in appearance, color, consistency and acceptability, but had a lower rating for taste and higher rating for aroma (Table 4).

Table 4. Sensory properties of tiger nut milk fortified with moringa seed.

\begin{tabular}{lcc}
\hline Property & $\begin{array}{c}\text { Fortified tiger nut } \\
\text { milk }\end{array}$ & $\begin{array}{c}\text { Unfortified tiger } \\
\text { nut milk }\end{array}$ \\
\hline Appearance & $8.23 \pm 0.01^{\mathrm{a}}$ & $8.65 \pm 0.20^{\mathrm{a}}$ \\
Color & $6.22 \pm 0.01^{\mathrm{a}}$ & $6.10 \pm 0.03^{\mathrm{a}}$ \\
Aroma & $4.98 \pm 0.00^{\mathrm{b}}$ & $4.51 \pm 0.01^{\mathrm{a}}$ \\
Taste & $5.50 \pm 0.01^{\mathrm{a}}$ & $7.50 \pm 0.10^{\mathrm{b}}$ \\
\hline
\end{tabular}




\begin{tabular}{ccc}
\hline Property & $\begin{array}{c}\text { Fortified tiger nut } \\
\text { milk }\end{array}$ & $\begin{array}{c}\text { Unfortified tiger } \\
\text { nut milk }\end{array}$ \\
\hline Consistency & $6.70 \pm 0.00^{\mathrm{a}}$ & $7.00 \pm 0.01^{\mathrm{a}}$ \\
Acceptability & $5.76 \pm 0.01^{\mathrm{a}}$ & $6.70 \pm 0.05^{\mathrm{b}}$ \\
\hline
\end{tabular}

\subsection{Discussion}

All foods contain some microorganisms inherent in them, these may come from the environment or the part of normal flora of the food raw materials. The results obtained in this study for the microbial quality are within the approved limit for ready to eat foods and beverages by NAFDAC in Nigeria. They are also in agreement with the observation of Akoma et al. [15] who reported similar range in their study. The absence of coliforms and enteric bacteria in the kunun samples produced in this study is at variance with the report of Akoma et al. [15] who reported coliform contamination of street hawked sweetened tiger nut milk samples in Northern Nigeria. The difference may be due to the strict aseptic measures adopted during the sample production in the laboratory. Also, the coliforms in the street hawked tiger nut milk may have been introduced into the milk during dilution with water during production by these producers in order to increase their profit margin. Such dilution of the product with water lowers the quality and increases the risk of contamination with pathogenic organism especially if the water source is of poor quality.

The microbial species isolated from the samples are not pathogenic in nature and are usually associated with plant materials. Most of these organisms have been reported by Oranusi et al. [16] to take part in fermentation of various types of plant products and they may have been introduced into the product from the air in the production area as well as during handling. These organisms if not removed after production may cause fermentation in the product leading to total spoilage of the product as observed by Umaru et al. [17].

The high moisture content of the tiger nut milk suggests that it may not have good keeping quality. High moisture content in a product is a precursor to its perishability, since most spoilage bacteria survive well at high moisture level [18]. Also the significant increase in the lipid and protein content of the fortified tiger nut milk may be due to the high level of these compounds in the moringa seed. High fat content of tiger nut milk may indicate high values of oil soluble vitamins such as vitamins A, D, E and K. Also, the higher fat content of the fortified tiger nut milk may be linked with the high level of oil in the seed of moringa [10].

The higher protein content of fortified tiger nut milk sample suggests that moringa seed may contain enough protein to ameliorate protein deficiency usually observed in tiger nut based products. Ash content is an aggregate of minerals in a food substance, the moderate ash content found in the fortified tiger nut milk sample suggest that fortified tiger nut milk may contain essential minerals needed by the body. Fiber content of tiger nut milk rank well with that of fruits and matured leguminous seeds [19]. Therefore, tiger nut milk if consumed, the fiber content could play its important role in the reduction of pressure and transit time of food through the body aiding to digestion. Fiber aids in alleviation of flatulence problem thus, tiger nut fiber could be explored in formulating diets for treating indigestion, constipation and non-communicable diseases such as colon cancer, diverticulosis, coronary heart disease and obesity [20].

The result of the mineral composition of the tiger nut milk fortified with moringa seed is presented in Table 3. The table shows that the fortified milk had higher level of all the minerals than unfortified milk. The richness of the fortified milk essential minerals such as magnesium, potassium, calcium, sodium and phosphorus suggests that fortification of tiger nut milk with moringa seed may help to reduce micronutrient deficiency in humans. Tiger nut milk fortified with moringa seed could be taken by young and old (children, adolescents, adults, pregnant and lactating mothers) for its high energy and preventive or protective nutrients. These nutrients could significantly contribute to the body's metabolic processes, refreshing the body as well [19].

Magnesium provides bone strength, aids enzyme, nerve and heart functions [10]. Tiger nut milk could contribute adequate $\mathrm{Mg}$ to the daily need of children. Phosphorus enhances quick release of energy in the body and may combine with calcium for bone and teeth development [6]. Tiger nut milk are relatively low in calcium and sodium. Recent studies on blood pressure showed that a diet rich in potassium and magnesium but low in sodium can lead to a decrease in blood pressure within days of beginning a specific diet [20]. Potassium aids nerve impulse transmission and it is a major cation of intracellular fluid [11]. High potassium to low sodium ratio of tiger nut milk therefore, may be imperative in diet formulations for patients with high blood pressure and oedema as well.

In the sensory evaluation, tiger nut milk fortified with moringa seed had comparable rating to the unfortified milk in appearance, color, consistency and acceptability but had a lower rating for taste and higher rating for aroma. This may be attributed to the level of sugar naturally present in tiger nuts. Lower rating of the fortified milk may be attributed to the astringent taste of moringa seed and the difference in the acceptability may be due to the difference in chemical composition as may have been introduced by the moringa seed in the fortified milk sample [18].

\section{Conclusions}

From the results obtained in this study, it can be concluded that fortification of tiger nut milk with moringa seed significantly enhanced its nutritional properties as shown in the proximate and mineral content results obtained. Also, fortification of tiger nut milk with moringa seed did not have significant effect on the sensory properties of the tiger nut milk. However, more studies should be done to determine the keeping quality/shelf-life of the tiger nut milk fortified with moringa seed and more research should be done to know the effective fortification dose of moringa seed in tiger nut milk.

\section{Conflict of interest}

The authors declare no conflict of interest 


\section{References}

[1]. P. McNamara, Amino Acid Analysis Data of Tiger Nut Milk Extract. Law Labs LTD Alta Bioscience (Unpublished) $1-67$.

[2]. Food and Agriculture Organization. Fermented Fruits and Vegetables: A Global Perspective. FAO Agricultural Services Bulletin No. 134, Rome 1998.

[3]. R. Abaejoh, I. Djomdi, R. Ndojouenkeu, Characteristics of tiger nut (Cyperus esculentus) tubers and their performance in the production of a milky drink, J. Food Process. Preserv. 30 (2006) 145-163

[4]. A.O. Obadina, O.B. Oyawole, A.A. Ayoola. Quality assessment of Gari produced using rotary drier; in "Food Processing, Methods, Techniques and Trends", edited by V.C. Bellinghouse, Nova Science Publishers 2008.

[5]. L. Bosch, A. Alegría, R. Farré. RP-HPLC Determination of tiger nut and orgeat amino acid contents, Food Sci. Tech. Int. 11 (2005) 33-40.

[6]. R. Farre, Nutritional and dietetic aspects of tiger nut, Tiger nuts traders, S.L. Export. www.tiger nuts.com, 2003. Accessed January, 2019

[7]. M. Bixquert, Digestive aspects of tiger nuts. Tiger nuts traders, S.L. Export. www.tiger nuts.com, 2003. Accessed January, 2019.

[8]. J.M. Valls, Effects of tiger nut on heart diseases and related aspects tiger nuts. Tiger nuts traders, S.L. Export. www.tiger nuts.com, 2003. Accessed January, 2019.

[9]. M. Moore, Documents prepared for bottle green for the product tiger white, Miam Ltd., pp. 1-22, 2004.

[10]. V. Abioye, M. Aka, Proximate composition and sensory properties of moringa fortified maize-ogi, J. Nutr. Food Sci. S12 (2015) 001. DOI:10.4172/2155-9600.S12-001

[11]. L.H. Allen, B. De Benoist, O. Dary, R. Hurrell. Guidelines on food fortification with micronutrients, 2006: 23-65. World Health Organization. http://www.who.int/nutrition/publications/guide_f ood_fortification_ micronutrients.pdf accessed on May 13th 2019.

[12]. Clinical and Laboratory Standards Institute (CSLI). (2014). Performance Standards for Antimicrobial Susceptibility Testing, TwentyFourth Informational Supplement, CSLI document M100-S24, Wayne, PA, United States. pp 50-57.

[13]. Association of Analytical Chemists. Official Method of Analysis (18 ${ }^{\text {th }}$ edn). Association of Analytical Chemists. Washington DC. pp 32-58, 2005.

[14]. K. Johoun, Method of food analysis, second edition, Academic Press, pp. 23-45, 2007.

[15]. O. Akoma, E.A. Jiya, D.D. Akumka, E. Mshellia, Influence of malting on the nutritional characteristics of kununzaki, African J. Biotechnol. 5 (2006) 996-1000.

[16]. S.U. Oranusi, V.J. Umoh, J.K.P. Kwaga, Hazards and critical control points of kunun-zaki, a nonalcoholic beverage in Northern Nigeria, Food Microbiology 20 (2003) 127-132.

[17]. G.A. Umaru, I.S. Tukur, U.A. Akensire, Z. Adamu, O.A. Bello, A.H.B. Shawulu, M. Audu, Microflora of kunun-zaki and sobo drinks in relation to public health in Jalingo Metropolis, North-Eastern Nigeria, Int. J. Food Res. 1 (2014) $16-21$.

[18]. M.J. Pelczar, E.C.S. Chan Noel, R. Krieg, Microbiology: Concepts and applications, p. 843, Mc Graw-Hill INC International Edition 2005.

[19]. J. Osagie, L. Eka. Editors: Nutrition Quality of Plants Foods, Edited by Osagie and Eka, Published by the Post-Harvest Research Unit of the Department of Biochemistry University of Benin, Benin City Nigeria, 1998.

[20]. G.M. Wardlaw, W.M. Kessel. Perspective in nutrition, pp. 101-123, 5th ed. Mc-Graw Hill 2002.

Received: 26.08 .2019

Received in revised form: 08.11.2019

Accepted: 10.11.2019 